\title{
BUILDING COALITIONS: Turf Issues
}

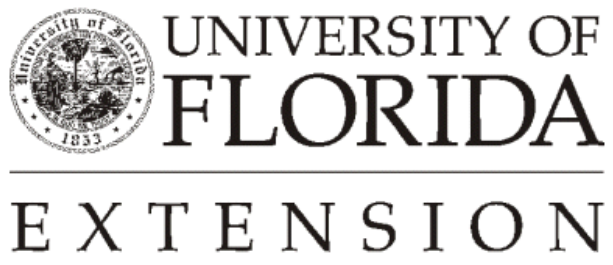

Institute of $\mathbf{F}_{\text {ood and }} \mathbf{A}_{\text {gricultural }} \mathbf{S}_{\text {ciences }}$ 
Organizations will join coalitions or collaborations because they see benefits of combining resources to work toward a common goal. Dealings between organizations are usually harmonious. On occasion, controversy develops. Sometimes it involves competition; occasionally it escalates into conflict. When left unresolved, this tension can often seriously damage the efforts of some or all the partners to reach the common goal. This fact sheet will examine "turf issues" as one source of organizational tension. It will discuss what it is, how it happens and what to do. Suggestions will include situations where it is already noticeable, but also offer tips on how it can be avoided.

\section{"Turf-ism"--What Is It?}

"Turf-ism" is the non-cooperation or conflict between organizations with seemingly common goals or interests. They would normally be expected to work together in a given situation. The term "turf issues" is borrowed from street gang terminology. Every gang has its neighborhood or "turf' in which it operates, and it defends this area against other gangs (usually violently). This idea has its parallel in animal behavior in the idea of "territoriality." In this version, individual animals have their "home base" around their mating, feeding or nesting grounds that they defend against other animals, even those of the same species.

In theory, each organization has its "domain" or field of operation. It also has human and material resources, goals and tasks related to the goals. When relationships are formed by community and educational organizations, they agree to exchange resources. This is often called the "exchange theory" or organizational relations. In the effort to secure needed resources and reach goals, organizations often develop overlapping "domains." This may make them unexpectedly reluctant to enter the expected exchange. (Levine and White 1961) When this happens, a "turf battle" can take place.

\section{Why Does It Happen?}

Conflict usually involves perceptions of incompatible goals or threats to relationships. (Ross and Ross, 172) These perceptions lead to "turf protection" as organizations decide to "defend" their domain rather than share with another organization. Every time two organizations interact, they establish boundaries through "exchange" relationships. (Zald, 1969) The basic factor in triggering a "turf battle" is the degree of power surrendered or gained by the organizations involved. "Power" as used here is the ability to control or manage resources to accomplish a goal. If both organizations feel they will gain by working together or having access to an equal degree of power, cooperation continues. But if one organization feels it has too much to lose by continued cooperation, it begins to defend its "turf."

These "turf battles" can take place for three fundamental reasons, all related to the perceived effect on power:

1. If one organization perceives the other as a direct and regular competitor for resources that are not likely to be shared; 
2. If one organization perceives a "marginal cost" to the proposed cooperation in money, time or energy greater than perceived benefits of collaboration;

3. The degree of which the organization feels it is flexible to change its current goals, tasks and philosophy to adopt the course of action being proposed.

According to Zald, another reason for turf battles is the lack of knowledge or mistrust of the other organizations. If the target group or constituencies of two groups seem to overlap to a high degree, there is more likely to be cooperation. If one organization feels it does not have much in common with the proposed partner, it is less likely to feel the mutual benefits of the proposed action.

Turf battles also can result if one party in a proposed relationship feels the exchange will be unequal. This could happen in one of two ways. One organization may feel the proposed course of action is unilateral, that they have no real voice in deciding what or how it will happen. An organization also can feel the exchange would be unequal. It might feel that it would cost them too much in resources compared with the proposed benefit, or that another party stands to gain more resources than other partners. (Levine and White 1961 )

\section{When Does It Happen?}

The "domains" of organizations can overlap in several major ways:

Over goals--Although general goals of participating organizations seem mutually dependent, a particular proposal for join action is perceived to work against the interest of one of the intended partners or against another limited goal.

Example: A delinquency-prevention group declines to form a working relationship with a community center in a target neighborhood. They feel the center would be devoting too much attention to counseling other family members about other problems rather than counseling troubled youth. (Reid 1969)

Over resources--Proposals, requests for public or private funds, shared staff, supplies, facilities, etc. from other organizations, etc. may be competing. Sometimes one intended party is denied totally. Sometimes distribution is to both parties, but on an unequal basis. In other situations, conflict over resources might result from how many resources should be put into the joint effort, not from which gets more from a collaborative effort. (Reid 1969)

Example: Both 4-H and Boy Scouts apply to a service club for funds to plant trees on Arbor Day.

Over geography--One organization feels they provide some service to or represent interests of an area exclusively. To allow another organization to operate in the area may suggest that the first organization 
is not doing an adequate job. It also may be perceived as a duplication of effort, or a source of potential confusion to target audiences.

Example: Two organizations both propose to begin teen pregnancy prevention programs in the same neighborhood.

Over methods--Organizations have a general agreement on goals, but one feels the approach proposed to reach goals would be ineffective or counterproductive to other interests of an organization. In another form, one organization may feel a degree of "ownership" over an activity or technique that another organization plans to use.

Examples: One organization in a coalition proposes to work toward improving funding for new child care centers by writing proposals to local foundations. Another organization wants to endorse political candidates who favor increased state funding for establishing new centers.

An organization has held an annual "pancake breakfast" on Valentine's Day for the past five years to raise funds for its youth softball league. Another organization proposes that the coalition hold a county-wide pancake breakfast on President's Day to raise money to purchase drug abuse prevention coloring books.

Over identity or public perception--An organization feels that proposed cooperation would change how their organization is viewed by public (less powerful, more or less conservative, feels threatened by potential success of other partner).

Example: A school system with falling student reading achievement scores is asked to distribute flyers for a collaboration tutoring program.

Over personalities--A representative of one organization is personally disliked by staff of another or represents a political or organizational threat. Non-cooperation represents a chance for the first organization's representative to "win" or "damage" the other party.

Example: One organizational director is asked to serve on a coalition committee chaired by the director of another organization. He or she plans to run against that individual for chairperson of the group next year.

Each organization in a coalition or collaboration may have several goals and programs. The cooperative efforts may represent only a fraction of the total activity or domain of the organization.

\section{How To Avoid Turf Battles}

Long term it is better to avoid turf battles than to have to deal with them. Before initiating or becoming a member of a coalition, there are certain things to remember: 
1. A group's goals are never 100 percent compatible with the goals of each organization or person involved. The "domains" are not likely to overlap totally. Accordingly, each member must be prepared to compromise or modify his or her commitment to specific goals and to help other members adjust as necessary.

2. Enough time should be spent at first to clarify coalition goals and develop each member's commitment to them. The group should establish a consensus on the "domain" of action for the coalition and how the resources of members might relate. The higher the sense of common purpose, the higher the probability of harmonious relations between members.

3. Clearly relating the needs discussed to the potential available resources can help build early momentum and cooperation. It can avoid tackling a large, vague problem and create a positive climate by being capacity-centered or resource-centered rather than problem-centered. This can be especially important in coalitions designed to operate in a small, geographic area. (McKnight and Kretmann 1991 )

4. Knowing the relationship between the members' personal goals and the group's goals can suggest potential sources of agreement and disagreement and show results.

Organizations should think twice before inviting groups that have only a partial or marginal relationship to the coalition mission to join the group. Consulting newspaper files, and interviewing organizational representatives and residents can be good sources of basic information. (Cener 1988) It also can suggest future avenues of positive involvement for some members.

5. Large groups usually have an advantage in the information giving and "brainstorming" phases of problem solving. Still, they can be a potential disadvantage when the consensus needs to be reached. Between-meeting communication before a proposed action with major parties helps avoid surprises and helps make meetings more productive.

6. Structured subgroups may eliminate the disadvantage of limited interaction time between members of large groups who might need more clarification of points.

7. Negative feedback (whether verbal, nonverbal, a combination of both or silence) should not be permissible, especially when there is no attempt to compromise or come to consensus. Effective listening and speaking skills will eliminate misunderstandings. Raising questions versus stating one's opinion(s) will help reduce disagreements. (Hague )

Organizational relationships are complex. We can almost never know all we need to know at the time a decision must be made. When working in coalitions or collaborations, differences in the goals, resources, or fields of activity may arise between members. In a well-planned effort, the clarity of goals 
and benefits, open communication and a forum for discussion of differences can be the glue that holds things together and keeps momentum going.

\section{How to Solve a "Turf Battle"}

For Harold Goetzkow and John Gyr, group conflict has two basic dimensions-- substantive and affective. Substantive refers to conflicts primarily related to task. In the examples above, "turf battles" related to goals, methods, resources and geography would fall in this category. Affective conflicts relate to socio-emotional or interpersonal relations. (Ross and Ross, 139) Turf battles related to identity or personality as described above are conflicts of this type. Morton Deutsch also points out that affective disagreements may arise over preferences and nuisances, values, beliefs and the nature of relationships. (Ross and Ross, 138)

The first step in deciding how to best handle the disagreement within a coalition is to identify whether it is a substantive or affective conflict.

If the dispute is task-related, the coalition should use an orderly problem-solving process to focus and structure its efforts toward a solution. As Zald suggests, incorrect or incomplete information is often a major part of a turf dispute. To minimize or make amends for these gaps or misunderstandings, coalition leadership can use several techniques. Discussion at group meetings can include one or more information-seeking techniques built into agenda activities.

Group leaders also should be sensitive to improving communication and active listening during and between meetings. These could include questions from the chair, summary statements of what other members have just said and attempts to make sure questions from the floor are properly answered. Leadership might find it necessary to recommend certain items be clarified and reported on by the next meeting. Sometimes an ad hoc committee may be needed to recommend a course of action or work out a compromise.

For resolving psychological or affective disputes, Scheidel and Crowell suggest that coalitions have several avenues to attempt. The group should look for some way to translate or relate the conflict to a task issue. This defuses much of the emotional element. The coalition should try to keep the focus on the whole group arena rather than organizations involved in the disagreement. Leaders should encourage members to remain tolerant and restrain emotions and language. Coalitions should have a conflict management procedure developed just in case. (Ross and Ross, 172) 


\section{References}

Barker, Larry L., Kathy J. Wahlers, Donald J. Cegala and Robert J. Kibler. Groups In Process: An

Introduction to Small Group Communication. 2d ed. Englewood Cliffs: Prentice-Hall, Inc., 1983.

Center for Urban Affairs and Policy Research. Getting Connected: How to Find Out About Groups and Organizations in Your Neighborhood. Evanston: Northwestern University, 1988.

Coser, Lewis. The Functions of Social Conflict. New York: Free Press of Glencoe, 1969.

Levine, Sol and Paul White. "Exchange as a Conceptual Framework for the Study of Interorganizational Relationships." Administrative Science Quarterly (March 1961 ).

McKnight, John L. and John Kretzmann. Mapping Community Capacity. Neighborhood Innovations Network, A Center for Urban Affairs and Policy Research, Evanston: Northwestern University, 1991.

Reid, William J. "Interagency Coordination in Social Welfare: A Theoretical Approach to Analysis and Intervention." In Readings in Community Organization Practice, edited by Ralph M. Kramer and Harry Specht. Englewood Cliffs: Prentice-Hall, Inc., 1969.

Ross, Raymond S. and Jean R. Ross. Small Groups in Organizational Settings. Englewood Cliffs: Prentice-Hall, I Inc., 1988.

Zald, Mayer N. "Organizations As Politics: An Analysis of Community Organization Agencies." In Readings in Community Organization Practice, 1969.

\section{Authors}

Gregory P. Siek, Assistant Professor, County Extension Agent,4-H, Ohio Cooperative Extension Service, Th Ohio State University.

Carla E. Hague, Associate Professor, County Extension Agent, 4-H, Ohio Cooperative Extension Service, The Ohio State University.

(C) 1992 The Ohio State University

DARCS Ohio Cooperative Extension Senvice 
This series on Coalition Building was developed by The Ohio Center For Action on Coalition Development for Family and High Risk Youth, Richard Clark, Ph.D., Director. It has been adapted for County Extension Faculty in Florida to facilitate work with local and regional organizations and groups such as non-profits, cooperatives, county extension associations, and others that might benefit from a plan for working together to achieve support for mutual goals.

This document is FY506, Part 14 of the 16 part series adapted for use in Florida by Elizabeth B. Bolton, Professor, Community Development and Lisa Guion, Assistant Professor, Program Planning and Evaluation; Department of Family, Youth and Community Sciences, Florida Cooperative Extension Service, Institute of Food and Agricultural Sciences, University of Florida, Gainesville, 32611-0310.

Reprinted with permission March, 1997. Revised April, 2002.

The Institute of Food and Agricultural Sciences is an equal opportunity/affirmative action employer authorized to provide research, educational information and other services only to individuals and institutions that function without regard to race, color, sex, age, handicap, or national origin. For information on obtaining other extension publications, contact your county Cooperative Extension Service office.

Florida Cooperative Extension Service/Institute of Food and Agricultural Sciences/University of Florida/Christine Taylor Waddill, Dean 